\title{
Metamerism Influence ON THE PRINTING QUALITY OF DIFFERENT DIGITAL OFFSET PRINTING TECHNIQUES
}

\author{
ZJAKIC, I.; BERTIC, I. \& NOVAKOVIC, M.
}

Abstract: Metamerism is appearance which influences the quality of the graphic product. The research of metamerism appierence was performed by measuring the integral inking density in two digital offset printing techniques: in digital offset printing technique on the principle of electrophotography with liquid toner and the in digital offset waterless printing technique. Measuring of prints was performed at lighting with light sources A, D50 and F2. The reproduction of the colour space dependent on metamerism was presented in CIE $L * a * b *$ diagrams. The measuring results present the appearance of metamerism of solid tone foe all primary colours except the black as well as for red, blue and green. The prints were obtained by printing on the fine art paper. They were produced on the newest offset machine INDIGO, and on the Heidelberg DI which prints without water.

Key words: Metamerism, Printing, Ink, Quality
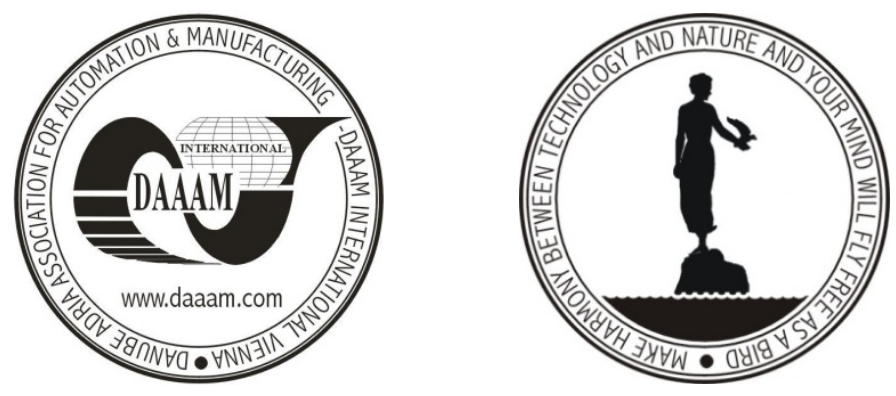

Authors' data: Prof. Ass. Zjakic, I[gor]; B.Sc. Graph. Eng. Bertic, I[rena]; Novakovic, M[arijana], Faculty of Graphic Arts, Getaldiceva 2, 10000, Zagreb, HR, zjakic@grf.hr, irena.bertic@grf.hr, marra@dudu.ro

This Publication has to be referred as: Zjakic, I[gor]; Bertic, I[rena] \& Novakovic, M[arijana] (2008). Metamerism Influence on the Printing Quality of Different Digital Offset Printing Techniques, Chapter 81 in DAAAM International Scientific Book 2008, pp. 977-986, B. Katalinic (Ed.), Published by DAAAM International, ISBN 978-3-901509-66-7, ISSN 1726-9687, Vienna, Austria

DOI: $10.2507 /$ daaam.scibook.2008.81 